\title{
Chemokines, lymphocytes, and HIV
}

J.M. Farber
Laboratory of Clinical Investigation, National Institute of Allergy and Infectious

Diseases, Bethesda, MD, USA
Correspondence

J.M. Farber

Laboratory of Clinical

Investigation

National Institute of Allergy

and Infectious Diseases

Building 10, Rm $11 \mathrm{~N}-228$

10 Center Drive, MSC 1888

Bethesda, MD 20892-1888

USA

Fax: 301-496-7383

E-mail: joshua_farber@nih.gov

Presented at the International Meeting on Cytokines, Angra dos Reis, RJ, Brasil, November 24-28, 1996.

Received September 4, 1997

Accepted September 22, 1997 .....................

\section{Abstract}

Chemokines are members of a family of more than 30 human cytokines whose best-described activities are as chemotactic factors for leukocytes and that are presumed to be important in leukocyte recruitment and trafficking. While many chemokines can act on lymphocytes, the roles of chemokines and their receptors in lymphocyte biology are poorly understood. The recent discoveries that chemokines can suppress infection by HIV-1 and that chemokine receptors serve, along with CD4, as obligate co-receptors for HIV-1 entry have lent urgency to studies on the relationships between chemokines and lymphocytes. My laboratory has characterized Mig and Crg-2/IP-10, chemokines that are induced by IFN- $\gamma$ and that specifically target lymphocytes, particularly activated $\mathrm{T}$ cells. We have demonstrated that the genes for these chemokines are widely expressed during experimental infections in mice with protozoan and viral pathogens, but that the patterns of mig and crg-2 expression differed, suggesting non-redundant roles in vivo. Our related studies to identify new chemokine receptors from activated lymphocytes resulted in the cloning of STRL22 and STRL33. We and others have shown that STRL22 is a receptor for the CC chemokine MIP-3 $\alpha$, and STRL 22 has been renamed CCR6. Although STRL33 remains an orphan receptor, we have shown that it can function as a co-receptor for HIV-1 envelope glycoproteins, and that it is active with a broader range of HIV-1 envelope glycoproteins than the major co-receptors described to date. The ability of STRL33 to function with a wide variety of envelope glycoproteins may become particularly important if therapies are instituted to block other specific co-receptors. We presume that investigations into the roles of chemokines and their receptors in lymphocyte biology will provide information important for understanding the pathogenesis of AIDS and for manipulating immune and inflammatory responses for clinical benefit.

\section{Introduction}

Chemokines are ancestrally related cytokines that signal through seven-transmembrane domain, G protein-coupled receptors, and whose best-described activities are as chemotactic factors (reviewed in Ref. 1). More than 30 human chemokines have been
Key words

- Cytokines

- Lymphoid cells

- HIV-1

- Receptors described. With the exception of lymphotactin and fractalkine, chemokines fall into two subfamilies: the CXC subfamily whose genes are clustered primarily on chromosome 4 in humans and in which the first two of four invariant cysteines are separated by a single variant residue, and the CC subfamily whose genes are clustered primarily on chromo- 
some 17 in humans and in which cysteines one and two are adjacent. Most of the CC chemokines, such as MCP-1 and RANTES, target monocytes and lymphocytes, and several target eosinophils. Most of the CXC chemokines, i.e., those containing the ELR motif, such as IL-8, target neutrophils. Mig, Crg-2/IP-10, and SDF-1 are non-ELR CXC chemokines. As described below, Mig and Crg-2/IP-10 target T cells (2,3), while SDF1 targets both $T$ cells and monocytes (4). Crg-2 and IP-10 are mouse and human homologues of each other, respectively.

In general, relationships between chemokines and their receptors are promiscuous. Most CC chemokines, for example, can signal through more than one receptor and as a rule, chemokine receptors can be activated by more than one chemokine ligand. Chemokines, in addition to their activities as chemotactic factors, can induce integrinmediated adhesion to activated endothelial cells (5), can act as both stimulators (6) and inhibitors (7) of proliferation of myeloid progenitor cells, can function as angiogenic (8) and angiostatic (9) factors, and can inhibit tumor growth in experimental models (10).

Recently, the CC chemokines MIP-1 $\alpha$, MIP- $1 \beta$ and RANTES, and later, the CXC chemokine SDF-1, were shown to be able to suppress infection by HIV-1 (11-13). Likewise, it was discovered that chemokine receptors were the long-sought human co-receptors for HIV-1 (14) and that the differences in tropisms among HIV-1 strains correlated with the strains' differential uses of specific chemokine receptors, with $T$ cell line-tropic strains using CXCR4 and macrophage-tropic strains using CCR5 (15-19). While all HIV-1 strains replicate in peripheral blood lymphocytes, most primary isolates, particularly those isolated early in disease, will grow in macrophages and not in immortalized $\mathrm{T}$ cell lines, while laboratory-adapted viruses and some viruses isolated late in infection grow in $\mathrm{T}$ cell lines in preference to macrophages. The critical role for CCR5 in
HIV disease was emphasized by the discovery that, with a few notable exceptions (2022), individuals homozygous for an inactivating deletion in the CCR5 gene were resistant to HIV-1 infection (23-26).

Despite the work done to date, major questions about chemokines and their receptors remain to be answered, such as: What are the precise roles of specific chemokines and chemokine receptors in physiology and pathophysiology in vivo? What are the activities and relationships among the chemokines and chemokine receptors newly discovered through the recent methods applied to gene discovery? These questions are particularly germane to considerations of the roles of chemokines in lymphocyte biology. These roles are likely to be complex, based on the large number of chemokines that target lymphocytes and the heterogeneity in lymphocyte populations. Moreover, understanding the relationships between chemokines and lymphocytes has become more pressing given the recent discoveries on the importance of chemokine receptors in HIV infection. The discussion below will focus on recent data from my laboratory on two chemokines, Mig and Crg-2/IP-10, that specifically target lymphocytes and on two novel seven-transmembrane domain proteins, STRL22 and STRL33 - one proven to be and the other presumed to be a chemokine receptor - that are expressed in lymphocytes.

\section{Studies on Mig and Crg-2/IP-10}

Initial studies in vitro showed that the genes for both murine (Mu) Mig and Crg-2 were induced dramatically by rIFN- $\gamma$ to more than 400-fold of baseline levels in a mouse macrophage cell line (27-29). Unlike mig, crg-2/IP-10 could also be induced by IFN- $\alpha$ and $-\beta$, and by lipopolysaccharide (28-30). In addition to macrophages, mig and crg- $2 /$ IP-10 are induced in a wide range of cell types, including hepatocytes, endothelial cells, fibroblasts, and keratinocytes (Ebnet 
K, Farber JM and Shaw S, unpublished results; 30,31).

We have purified recombinant human Mig (rHuMig), rMuMig, and rCrg-2 from transfected $\mathrm{CHO}$ cell lines and/or from insect cells infected with recombinant baculoviruses. We demonstrated that HuMig was secreted as a collection of polypeptides due to carboxy-terminal truncations, a form of processing that has not been described for other chemokines (2). We demonstrated that rHuMig induced a calcium flux in activated human $\mathrm{T}$ cell lines derived from tumors (tumor infiltrating lymphocytes, TIL) and phytohemagglutinin (PHA)-activated peripheral blood lymphocytes (PBL), but not in monocytes, granulocytes, or immortalized B cell lines. The purified rMuMig and rCrg-2 were also able to induce calcium fluxes in TIL. Using TIL, chemotaxis to rHuMig was demonstrated. The carboxyterminal truncated rHuMig was much less $(1 / 300)$ active in the calcium flux assay than the full-length protein, but did not act as an rHuMig antagonist, suggesting that the carboxy-terminal domain is important for binding to the HuMig receptor. We demonstrated that rHuMig and IP-10 could each desensitize cells to the response to the other, consistent with their sharing a receptor. Our suppositions were confirmed by the subsequent identification by others of CXCR3, a receptor shared by HuMig and IP-10 and expressed specifically on activated lymphocytes (32). Taken together, these data suggest that Mig and IP-10 are unusual among chemokines - unlike the ELR CXC chemokines or the $\mathrm{CC}$ chemokines described to date - in specifically targeting lymphocytes, and in particular activated $\mathrm{T}$ cells.

As part of studies of the biology of Mig and $\mathrm{Crg}-2$, and in collaboration with Ricardo Gazzinelli, Gunasegaran Karupiah, and Alan Sher at the NIH, we analyzed the expression of Mumig and crg-2 in mice during acute experimental infections with Plasmodium yoelii, Toxoplasma gondii, and vaccinia vi- rus (33). During these infections, the genes for MuMig and Crg-2 were both dramatically induced in multiple organs. The genes differed, however, in their dependence on inducers and in their relative levels of expression among the organs. The expression of Mumig, unlike crg-2, was absolutely dependent on IFN- $\gamma$. The dependence of Mumig induction on IFN- $\gamma$ was demonstrated most dramatically in infection of IFN- $\gamma$ knockout mice with $T$. gondii, where there was no Mumig mRNA detected by Northern analysis. In each of the infections analyzed, the Mumig gene was expressed at highest levels in the liver, in some cases clearly distant from the primary site of infection and inflammation. This was not the case for crg2 , which was induced to highest levels in those tissues that also showed the most dramatic induction of IFN- $\gamma$.

These data suggest that MuMig may have a systemic role during infection unrelated to influencing local leukocyte trafficking. Moreover, these studies make the point that part of the biological advantage in creating and retaining genes for chemokines with redundant activities may be the ability to independently and differentially regulate expression of these proteins in vivo depending on the stimuli and the tissue. At the level of the organism, each chemokine is likely to serve a non-redundant function.

Identification of the novel chemokine receptors STRL22 and STRL33

Our interest in the activities of Mig, Crg2/IP-10 and other chemokines on lymphocytes led us to screen lymphocytes for new chemokine receptors. We chose to do this using RT-PCR and pools of degenerate primers based on conserved sequences in the transmembrane domains of known receptors, and we used as our starting material RNA prepared from human TIL that we had shown to respond to a panel of chemokines and express mRNAs for many of the known 
chemokine receptors. From this TIL mRNA we isolated fragments for 11 receptors, among which were two novel sequences that we designated STRL22 (34) and STRL33 (35), for seven-transmembrane domain receptors from lymphocytes, clones 22 and 23, respectively. For STRL22, we isolated both genomic and cDNA clones and for STRL33 we isolated cDNA clones. The cDNAs were obtained from a library we constructed from a TIL line.

Sequence comparisons revealed that STRL22 and STRL33 showed identities at $37 \%$ of their amino acid residues and were related to chemokine receptors. They were, however, more closely related to the orphan receptors GPR-9-6 and EBI1 than to the known CXC chemokine receptors (CXCRs) or $\mathrm{CC}$ chemokine receptors (CCRs). The genes for STRL22 and STRL33 are located on chromosomes 6 and 3, respectively. Both genes are prominently and primarily expressed in a range of lymphoid tissue, although STRL22 is also expressed in pancreas and STRL33 in placenta. In leukocyte populations, both receptor genes are expressed in TIL but not in a number of immortalized $\mathrm{T}$ cell lines or in monocytes or granulocytes. STRL22 is expressed in resting PBL and in a B lymphoblastoid line, while STRL33 is poorly expressed in resting PBL, but prominently induced in PBL by activation in vitro with PHA and ionomycin.

To identify agonists for STRL22 and STRL33, expression vectors containing genomic or cDNA sequences were transfected into human embryonic kidney 293 cells. Cell lines with high levels of receptor mRNA expression were tested in the calcium flux assay with chemokines as well as with a variety of crude supernatants from cultured cells. No signals were found with the STRL33transfected cells.

For STRL22-transfected cells, the CKß4 CC chemokine, recently provided to us by Human Genome Sciences, Inc.Inc. (Rockville, MD), produced a signal. Initial descriptions of the $C K \beta 4$ chemokine have now been published under the names LARC (36), MIP-3 $\alpha$ (37), and Exodus (38), and for the sake of clarity I will use the name MIP-3 $\alpha$. The MIP$3 \alpha$ gene is expressed in some lymphoid tissue and liver, and MIP- $3 \alpha$ is active as a chemotactic factor for lymphocytes, but not for monocytes or granulocytes. In addition to identifying STRL22 as a receptor for MIP$3 \alpha$, we have shown that MIP-3 $\alpha$ produces a calcium signal in TIL expressing STRL22, and in freshly isolated PBL (39). The ability of MIP- $3 \alpha$ to produce a calcium flux in freshly isolated PBL is noteworthy, since in studies with a broad panel of both $\mathrm{CC}$ and CXC chemokines, we have not detected calcium responses in PBL unless the cells have first been activated in vitro (Rabin RL and Farber JM, unpublished results).

Of the 27 chemokines we have tested, only MIP-3 $\alpha$ signalled through STRL 22 . In cross-competition binding studies using [ $\left.{ }^{125} \mathrm{I}\right]-\mathrm{MIP}-3 \alpha$ and a number of unlabelled $\mathrm{CC}$ chemokines, done in collaboration with Ralph Alderson of Human Genome Sciences, only unlabelled MIP- $3 \alpha$ was able to inhibit [ $\left.{ }^{125} \mathrm{I}\right]-M I P-3 \alpha$ binding to STRL22-transfected cells. Taken together, these data indicate - in contrast to the promiscuous relationships among other chemokines and chemokine receptors - a highly specific interaction between MIP-3 $\alpha$ and STRL22. Data identifying STRL22 as a receptor for MIP-3 $\alpha$ have been published by others (40). The finding of a chemokine ligand for STRL22 has led to it being re-named CCR6.

In collaboration with Edward Berger's laboratory at NIH, using a cell-cell fusion assay, we tested STRL22 and STRL33 for activities as fusion/entry cofactors for HIV. Cells expressing CD4 and transfected with DNA encoding STRL33 were able to fuse with cells expressing envelope glycoproteins (Envs) from HIV-1 (35). Similar assays using STRL22 have thus far been negative. Of greatest interest and, in contrast with the major known HIV-1 co-receptors, CXCR4 
and CCR5, STRL33 could mediate fusion with cells expressing Envs from HIV-1 strains of diverse tropisms: from $\mathrm{T}$ cell line-tropic, laboratory-adapted strains, from macrophage-tropic strains, and from dual-tropic strains. Importantly, as noted above, STRL33 is expressed in activated PBL, activated T cell lines and in lymphoid tissue, i.e., in natural targets of HIV-1.

Using Jurkat $\mathrm{T}$ cell clonal lines that we derived after transfection with DNA encoding STRL33 we have demonstrated, in collaboration with Keith Peden at the FDA, that STRL33 can mediate productive, spreading infection of HIV-1 $1_{\mathrm{ELI} 1}$. Taken together, these data demonstrate that STRL33 is active with a broader range of Envs than has been described for any of the co-receptors discovered to date. This exceptional attribute suggests that STRL33 may be of particular value in unraveling the structural determinants of Env/co-receptor interactions and will be of importance in the pathogenesis of HIV disease. This also suggests that strains of HIV 1 that use CCR5 or CXCR4 preferentially may nonetheless be able to adapt to use STRL33 efficiently if selective pressure is applied by therapeutic attempts to block the use of the primary co-receptors.

Our work has focused on identifying and characterizing chemokines and chemokine receptors that convey signals among macrophages, lymphocytes, and other cells as part of an immune response. Because these cellular interactions are involved in a wide range of infectious, inflammatory and neoplastic diseases, identifying and characterizing chemokines and their receptors are of potential general medical importance. Just as for cytokines generally, it is possible that administering, mimicking, or inhibiting chemokines could find direct therapeutic application. Our presumption has been that chemokines act in a more limited way than their pleiotropic inducers such as IFN- $\gamma$ and TNF- $\alpha$. As compared with pleiotropic immunomodulators, their greater specificity of action would make chemokines and/or chemokine receptors more appealing therapeutic targets. Recent discoveries on the role of chemokines and chemokine receptors in AIDS have provided new opportunities to apply knowledge of these molecules to the therapy of human disease and have provided new urgency to understanding the molecular biology of the chemokine system.

\section{Acknowledgments}

Thanks are due to the members of my laboratory, Doron Amichay, Hwang-Ho Lee, Fang Liao, Matthew Park, Ronald Rabin, Geetika Sharma, and Craig Smith, and to our collaborators Ralph Alderson, Ghalib Alkhatib, Edward Berger, Ricardo Gazzinelli, Gunasegaran Karupiah, Brent Kreider, Keith Peden, Alan Sher, and John Yannelli for their contributions to the work reviewed above.

\section{References}

1. Baggiolini M, Dewald B \& Moser B (1997). Human chemokines: an update. Annual Review of Immunology, 15: 675-705.

2. Liao F, Rabin RL, Yannelli JR, Koniaris LG, Vanguri P \& Farber JM (1995). Human Mig chemokine: biochemical and functional characterization. Journal of Experimental Medicine, 182: 1301-1314.
3. Taub DD, Lloyd AR, Conlon K, Wang JM, Ortaldo JR, Harada A, Matsushima K, Kelvin DJ \& Oppenheim JJ (1993). Recombinant human interferon-inducible protein 10 is a chemoattractant for human monocytes and T lymphocytes and promotes $T$ cell adhesion to endothelial cells. Journal of Experimental Medicine, 177: 1809-1814.
4. Bleul CC, Fuhlbrigge RC, Casasnovas JM, Aiuti A \& Springer TA (1996). A highly efficacious lymphocyte chemoattractant, stromal cell-derived factor 1 (SDF-1). Journal of Experimental Medicine, 184: 11011109. 
5. Detmers PA, Lo SK, Olsen-Egbert E, Walz A, Baggiolini M \& Cohn ZA (1990). Neutrophil-activating protein 1 /interleukin-8 stimulates the binding activity of the leukocyte adhesion receptor CD11b/CD18 on human neutrophils. Journal of Experimental Medicine, 171: 1155-1162.

6. Broxmeyer HE, Sherry B, Lu L, Cooper S, Carow C, Wolpe SD \& Cerami A (1989). Myelopoietic enhancing effects of murine macrophage inflammatory proteins 1 and 2 on colony formation in vitro by murine and human bone marrow granulocyte/ macrophage progenitor cells. Journal of Experimental Medicine, 170: 1583-1594.

7. Graham GJ, Wright EG, Hewick R, Wolpe SD, Wilkie NM, Donaldson D, Lorimore S \& Pragnell IB (1990). Identification and characterization of an inhibitor of haemopoietic stem cell proliferation. Nature, 344: 442-444

8. Koch A, Polverini P, Kunkel S, Harlow L, DiPietro L, Elner $V$, Elner $S$ \& Strieter $R$ (1992). Interleukin-8 as a macrophage-derived mediator of angiogenesis. Science, 258: 1798-1801.

9. Maione T, Gray G, Petro J, Hunt A, Donner A, Bauer S, Carson H \& Sharpe R (1990). Inhibition of angiogenesis by recombinant human platelet factor-4 and related peptides. Science, 247: 77-79.

10. Sharpe RJ, Byers HR, Scott CF, Bauer SI \& Maione TE (1990). Growth inhibition of murine melanoma and human colon carcinoma by recombinant platelet factor 4 . Journal of the National Cancer Institute, 82: 848-853.

11. Cocchi F, DeVico AL, Garzino-Demo A, Arya SK, Gallo RC \& Lusso P (1995). Identification of RANTES, MIP- $1 \alpha$, and MIP-1 $\beta$ as the major HIV-suppressive factors produced by CD8+ T cells. Science, 270: 1811-1815.

12. Bleul CC, Farzan M, Choe H, Parolin C, Clark-Lewis I, Sodroski J \& Springer TA (1996). The lymphocyte chemoattractant SDF-1 is a ligand for LESTR/fusin and blocks HIV-1 entry. Nature, 382: 829-833.

13. Oberlin E, Amara A, Bachelerie F, Bessia C, Virelizier J-L, Arenzana-Seisdedos F, Schwartz O, Heard J-M, Clark-Lewis I, Legler DF, Loetscher M, Baggiolini M \& Moser B (1996). The CXC chemokine SDF-1 is the ligand for LESTR/fusin and prevents infection by T-cell-line-adapted HIV-1. Nature, 382: 833-835.

14. Feng $Y$, Broder CC, Kennedy PE \& Berger EA (1996). HIV-1 entry cofactor: functional cDNA cloning of a seven-transmembrane, G-protein-coupled receptor. Science, 272: 872-877.
15. Alkhatib G, Combadiere C, Broder CC, Feng $Y$, Kennedy PE, Murphy PM \& Berger EA (1996). CC CKR5: A RANTES, MIP-1 $\alpha$, MIP-1 $\beta$ receptor as a fusion cofactor for macrophage-tropic HIV-1. Science, 272: 1955-1958.

16. Deng H, Liu R, Ellmeier W, Choe S, Unutmaz D, Burkhart $M$, Di Marzio $P$, Marmon S, Sutton RE, Hill CM, Davis CB, Peiper SC, Schall TJ, Littman DR \& Landau NR (1996). Identification of a major co-receptor for primary isolates of HIV1. Nature, 381:661-666

17. Choe $H$, Farzan $M$, Sun $Y$, Sullivan $N$, Rollins B, Ponath PD, Wu L, Mackay CR, LaRosa G, Newman W, Gerard N, Gerard C \& Sodroski J (1996). The ß-chemokine receptors CCR3 and CCR5 facilitate infection by primary HIV-1 isolates. Cell, 85: 1135-1148.

18. Doranz BJ, Rucker J, Yi Y, Smyth RJ, Samson M, Peiper SC, Parmentier M, Collman RG \& Doms RW (1996). A dualtropic primary HIV-1 isolate that uses fusin and the B-chemokine receptors CKR-5, CKR-3, and CKR-2b as fusion cofactors. Cell, 85: 1149-1158.

19. Dragic T, Litwin V, Allaway GP, Martin SR, Huang $Y$, Nagashima KA, Cayanan C, Maddon PJ, Koup RA, Moore JP \& Paxton WA (1996). HIV-1 entry into CD4+ cells is mediated by the chemokine receptor CCCKR-5. Nature, 381: 667-673

20. Biti R, French R, Young J, Bennetts $B$ \& Stewart G (1997). HIV-1 infection in an individual homozygous for the CCR5 deletion allele. Nature Medicine, 3: 252-253.

21. O'Brien TR, Winkler $C$, Dean $M$, Nelson JAE, Carrington M, Michael NL \& White II GC (1997). HIV-1 infection in a man homozygous for CCR5 $\Delta 32$. Lancet, 349 1219.

22. Theodorou I, Meyer L, Magierowska M Katlama C, Rouzioux C \& Group SS (1997) HIV-1 infection in an individual homozygous for CCR5A32. Lancet, 349: 12191220.

23. Samson M, Libert F, Doranz BJ, Rucker J, Liesnard C, Farber C-M, Saragosti S, Lapoumeroulie C, Cognaux J, Forceille C, Muyldermans G, Verhofstede C Burtonboy G, Georges M, Imai T, Rana S, Yi Y, Smyth RJ, Collman RG, Doms RW, Vassart G \& Parmentier M (1996). Resistance to HIV-1 infection in Caucasian individuals bearing mutant alleles of the CCR5 chemokine receptor gene. Nature, 382: 722-725.
24. Liu R, Paxton WA, Choe S, Ceradini D, Martin SR, Horuk R, MacDonald ME, Stuhlmann H, Koup RA \& Landau NR (1996). Homozygous defect in HIV-1 coreceptor accounts for resistance of some multiply-exposed individuals to HIV1 infection. Cell, 86: 367-377.

25. Dean $M$, Carrington $M$, Winkler $C$, Huttley GA, Smith MW, Allikmets R, Goedert JJ, Buchbinder SP, Vittinghoff E, Gomperts E, Donfield S, Vlahov D, Kaslow R, Saah A, Rinaldo C, Detels R, Hemophilia Growth and Development Study, Multicenter AIDS Cohort Study, Multicenter Hemophilia Cohort Study, San Francisco City Cohort, ALIVE Study, Stephen J. O'Brien (1996). Genetic restriction of HIV1 infection and progression to AIDS by a deletion allele of the CKR5 structural gene. Science, 273: 1856-1862

26. Zimmerman PA, Buckler-White A Alkhatib G, Spalding T, Kubofcik J, Combadiere C, Weissman D, Cohen O, Rubbert A, Lam G, Vaccarezza M Kennedy PE, Kumraraswami V, Gorgi JV, Detels R, Hunter J, Chopek M, Berger EA, Fauci AS, Nutman TB \& Murphy PM (1997). Inherited resistance to HIV-1 conferred by an inactivating mutation in CC chemokine receptor 5: studies in populations with contrasting clinical phenotypes, defined racial background and quantified risk. Molecular Medicine, 3: 23-36.

27. Farber JM (1990). A macrophage mRNA selectively induced by $\gamma$-interferon encodes a member of the platelet factor 4 family of cytokines. Proceedings of the National Academy of Sciences, USA, 87 5238-5242.

28. Vanguri $P$ \& Farber J (1990). Identification of CRG-2: An interferon-inducible mRNA predicted to encode a murine monokine. Journal of Biological Chemistry, 265: 15049-15057.

29. Farber JM (1992). A collection of mRNA species that are inducible in the RAW 264.7 mouse macrophage cell line by gamma interferon and other agents. Molecular and Cellular Biology, 12: 15351545

30. Luster AD, Unkeless JC \& Ravetch JV (1985). $\gamma$ Interferon transcriptionally regulates an early-response gene containing homology to platelet proteins. Nature, 315: 672-676.

31. Luster AD \& Ravetch JV (1987). Biochemical characterization of a $\gamma$ interferon-inducible cytokine (IP-10). Journal of Experimental Medicine, 166: 1084-1097. 
32. Loetscher $M$, Gerber $B$, Loetscher $P$, Jones SA, Piali L, Clark-Lewis I, Baggiolini $M$ \& Moser $B$ (1996). Chemokine receptor specific for IP-10 and Mig: structure, function, and expression in activated TIymphocytes. Journal of Experimental Medicine, 184: 963-969.

33. Amichay D, Gazzinelli RT, Karupiah G, Moench TR, Sher A \& Farber JM (1996). Genes for chemokines MuMig and Crg-2 are induced in protozoan and viral infections in response to IFN- $\gamma$ with patterns of tissue expression that suggest nonredundant roles in vivo. Journal of Immunology, 157: 4511-4520

34. Liao F, Lee H-H \& Farber JM (1997). Cloning of STRL22, a new human gene encoding a $\mathrm{G}$ protein-coupled receptor related to chemokine receptors and located on chromosome 6q27. Genomics, 40: 175180.
35. Liao F, Alkhatib G, Peden KWC, Sharma G, Berger EA \& Farber JM (1997) STRL33, a novel chemokine receptor-like protein, functions as a fusion cofactor for both macrophage-tropic and T cell linetropic HIV-1. Journal of Experimental Medicine, 185: 1-9.

36. Hieshima K, Imai T, Opdenakker G, Damme JV, Kusuda J, Tei H, Sakaki Y, Takatsuki K, Miura R, Yoshie O \& Nomiyama H (1997). Molecular cloning of a novel human $\mathrm{CC}$ chemokine liver and activation-regulated chemokine (LARC) expressed in liver. Journal of Biological Chemistry, 272: 5846-5853.

37. Rossi DL, Vicari AP, Franz-Bacon K, McClanahan TK \& Zlotnik A (1997). Identification through bioinformatics of two new macrophage proinflammatory human chemokines, MIP-3 $\alpha$ and MIP-3ß. Journal of Immunology, 158: 1033-1036.
38. Hromas R, Gray PW, Chantry D, Godiska R, Krathwohl M, Fife K, Bell GI, Takeda J, Aronica S, Gordon M, Cooper S, Broxmeyer HE \& Klemsz MJ (1997). Cloning and characterization of Exodus, a novel ß-chemokine. Blood, 89: 3315-3322.

39. Liao F, Alderson R, Su S, Ullrich SJ, Kreider BL \& Farber JM (1997). STRL22 is a receptor for the CC chemokine MIP-3 $\alpha$. Biochemical and Biophysical Research Communications, 236: 212-217.

40. Baba M, Imai T, Nishimura M, Kakizaki M, Takagi S, Hieshima K, Nimiyama H \& Yoshie O (1997). Identification of CCR6, the specific receptor for a novel lymphocyte-directed CC chemokine LARC. Journal of Biological Chemistry, 272: 1489314898. 